\title{
Distribution and enrichment of mercury in Tibetan lake waters and their relations with the natural environment
}

\author{
Chengding $\mathrm{Li}^{1,4}$ • Qianggong Zhang ${ }^{1,2,3,6}$ - Shichang Kang ${ }^{1,2,3}$ - Yongqin Liu ${ }^{1,2}$. \\ Jie Huang ${ }^{1}$ - Xiaobo Liu ${ }^{1}$. Junming Guo ${ }^{1,4}$ - Kang Wang ${ }^{1,5}$ - Zhiyuan Cong ${ }^{1,2}$
}

Received: 16 September 2014 / Accepted: 6 April 2015 / Published online: 24 April 2015

(C) Springer-Verlag Berlin Heidelberg 2015

\begin{abstract}
Mercury (Hg) in aquatic ecosystems is of great concern due to its toxicity, bioaccumulation, and magnification in the food web. The Tibetan Plateau (TP) is endowed with the highest and largest lakes on earth, whereas $\mathrm{Hg}$ distribution and behavior in lake waters are least known. In this study, surface water samples from 38 lakes over the TP were collected and determined for the total $\mathrm{Hg}$ (THg) concentrations. Results revealed a wide range of THg concentrations from $<1 \mathrm{ng}$ to $40.3 \mathrm{ng} \mathrm{L}^{-1}$. THg in lake waters exhibited an increasing trend along the southeast to northwest transect over the TP. Strong positive correlations were observed between $\mathrm{THg}$ concentrations and salinity and salinity-related environmental variables,
\end{abstract}

Responsible editor: Philippe Garrigues

Electronic supplementary material The online version of this article (doi:10.1007/s11356-015-4498-3) contains supplementary material, which is available to authorized users.

Qianggong Zhang

qianggong.zhang@itpcas.ac.cn

1 Key Laboratory of Tibetan Environment Changes and Land Surface Processes, Institute of Tibetan Plateau Research, Chinese Academy of Sciences, Beijing 100101, China

2 CAS Center for Excellence in Tibetan Plateau Earth Sciences, Beijing 100101, China

3 State Key Laboratory of Cryospheric Sciences, Cold and Arid Regions Environmental and Engineering Research Institute, Chinese Academy of Sciences, Lanzhou 730000, China

4 University of Chinese Academy of Sciences, Beijing 100049, China

5 Center for Earth Observation Science, Department of Environment and Geography, University of Manitoba, Winnipeg R3T 2N2, Canada

6 Present address: Paul Scherrer Institute, Villigen CH-5232, Switzerland especially for total dissolved solids (TDS) and some of the major ions such as $\mathrm{Na}^{+}, \mathrm{K}^{+}$, and $\mathrm{Cl}^{-}$, suggesting the enrichment of $\mathrm{Hg}$ in saline lakes. The large-scale geographical pattern of climatic and environmental factors shows a decreasing precipitation and an increasing evaporation northwards and westwards and thereby induces gradient-enhanced enrichment of soluble substances in lake waters, which are likely to complex more $\mathrm{Hg}$ in northwestern TP. Our study provides the first comprehensive baseline data set of $\mathrm{Hg}$ in Tibetan lake waters and highlights the concurrent high $\mathrm{Hg}$ and salinity, representing valuable references and fundamental rules in further understanding the behavior and fate of $\mathrm{Hg}$ in lakes over the TP and perhaps high-altitude regions beyond.

Keywords Lake $\cdot$ Water $\cdot$ Mercury $\cdot$ Tibetan Plateau · Distribution $\cdot$ Enrichment

\section{Introduction}

Mercury $(\mathrm{Hg})$ is an ubiquitous environmental contaminant derived from both natural and anthropogenic sources (Mason et al. 1994; Nimick et al. 2013). Owning to its gaseous existence and long retention time in the atmosphere, $\mathrm{Hg}$ can be widely dispersed and transported over thousands of kilometers affecting oceanic and terrestrial environments in remote areas (Fitzgerald et al. 1998). Among diverse terrestrial ecosystems, lakes act as sentinels and integrators for environmental variations in their watersheds and airsheds and beyond (Schindler 2009) and represent important habitats for fish that can accumulate $\mathrm{Hg}$ to hazardous levels for human consumption (Mergler et al. 2007). Therefore, there is increasing attention being paid to $\mathrm{Hg}$ distribution, transformation, and bioaccumulation as well as their environmental implications in lake ecosystems all over the world. In the last few decades, efforts 
have been devoted to reveal consistent co-variation of $\mathrm{Hg}$ background levels in lake waters and sediments as well as rapid changes in fish $\mathrm{Hg}$ in response to regional/global atmospheric Hg deposition (Fliedner et al. 2014; Harris et al. 2007; Swain et al. 1992). Particularly, remote high-altitude lakes are further recognized as $\mathrm{Hg}$-sensitive ecosystems to $\mathrm{Hg}$ inputs (Krabbenhoft et al. 2002) and, therefore, are hotspots for understanding the modern cycling and historical changes of $\mathrm{Hg}$ in a regional and global context (Phillips et al. 2011).

The Tibetan Plateau represents the highest and largest landforms on earth and is one of the few areas globally that has remained untouched by local human disturbances. Owing to its cold climate and integration of diverse environments, there has been increasing interest in $\mathrm{Hg}$ contamination in the TP environments (Zhang et al. 2014). Despite Hg levels that were reported at natural background in the atmosphere, precipitation, soils, and glacier snow (Fu et al. 2012; Huang et al. 2012; Sheng et al. 2012; Zhang et al. 2012), historical reconstruction of atmospheric Hg using lake sediments revealed a clear and consistent increase of $\mathrm{Hg}$ induced by Asian $\mathrm{Hg}$ emission over the last few decades (Yang et al. 2010), underlining the importance of an integrated consideration of $\mathrm{Hg}$ cycle over the TP. The TP is endowed with the world's highest and largest group of high-altitude lakes, whereas the baseline of $\mathrm{Hg}$ and its behavior and fate in such unique environment remain almost non-existent, representing a major gap in fully understanding the background and cycle of $\mathrm{Hg}$ in the TP environments and the further linkage to regional and global environmental changes.

This study represents the first attempt to establish the comprehensive data set for $\mathrm{Hg}$ levels in lake waters over the TP and to reveal their distribution and potential influencing factors. The results represent valuable references and fundamental rules for further investigation on the behavior and fate of $\mathrm{Hg}$ in lake ecosystems and regional $\mathrm{Hg}$ biogeochemical cycling over the TP.

\section{Materials and methods}

\section{Site description}

The TP extends an area of more than $2 \times 10^{6} \mathrm{~km}^{2}$ with an elevation well above $4000 \mathrm{~m}$ a.s.l. (Liu and Chen 2000) and is surrounded by massive mountain ranges with Himalayan Ranges and Kunlun Ranges at its south and north, respectively. Climatically, the TP is dominated alternately by the Indian monsoon in summer and the westerly in winter, resulting a dramatic contrasting climate with warm-wet summer and cold-dry winter, respectively. The annual mean precipitation varies a large range from $>4000 \mathrm{~mm}$ in the southeast to $<50 \mathrm{~mm}$ in the northwest (Sun et al. 1990). Owing to sparse population density and almost negligible industrial activities, the TP is considered one of most remote and pristine regions in the world and therefore serves as an ideal natural laboratory for studies in environmental change at a range of scales.

Known as "the Roof of the World," the TP holds the most extensive area of glaciers outside the polar regions, acting as the source of many major rivers in Asia, including the Yangtze River, the Yellow River, the Yarlung Zangbu/Brahmaputra, and the Mekong River. Besides considerable glacial aggregates and rivers, the TP is endowed with the world's highest and largest group of high-altitude lakes, with 1091 lakes larger than $1 \mathrm{~km}^{2}$ and 346 lakes larger than $10 \mathrm{~km}^{2}$, accounting for over half of the lake area in China (Ma et al. 2011; Wang and Dou 1998). Lakes over the TP are different in size, altitude, and shape, with most of which embedded in intermountainous basins and valleys as endorheic lakes (Wang and Dou 1998). Owing to the atrocious climate and environment, lakes over the TP have been less investigated.

In this study, water samples were collected from 38 lakes interspersed over a large geographical scale on the TP. Basically, these lakes were chosen for sampling based on their geographical location (relative ease of access) and the representative of regional surface lake water chemistry. The catchment of the studied lakes is mostly covered by desert vegetation or high frigid meadow. These lakes varied contrastively in characteristics with the lake areas from $0.10 \mathrm{~km}^{2}$ (no. 34 , Qiangyong Co.) to $2015 \mathrm{~km}^{2}$ (no. 33, Nam Co.) and the altitudes from $3469 \mathrm{~m}$ (no. 38, Basom tso) to $5145 \mathrm{~m}$ a.s.l. (no. 14, Dajia Co), representing one of the most comprehensive and representative lake clusters for investigating the distribution of $\mathrm{Hg}$ in lake waters over the TP (Table 1; Electronic supplementary material Table S1).

\section{Field sampling}

During the summer of 2010 and 2011, an interdisciplinary research on Tibetan lakes were conducted along the southeast-northwest transect across the TP (Fig. 1). For Hg sampling, at each lake site, at least one offshore surface water sample $(10-15 \mathrm{~cm})$ was collected. All Hg samples were taken in replicates with two persons following strictly the "Clean hands-Dirty hands" sampling protocol (Fitzgerald 1999). Operators were worn non-powder vinyl clean room gloves all times to minimize potential contamination. $\mathrm{Hg}$ samples were stored in 50-mL new polypropylene Falcon tubes and were acidified to $0.4 \%$ with ultrapure hydrochloride acid (BV - III grade from Beihua Chemical, China) on site (Zhang et al. 2012). Field blank samples were obtained by filling ultrapure water in situ for each sampling lake and were handled as samples. All samples were tightly sealed, double-packed in Ziploc bags, and then stored in a cooler before transported back laboratory.

Major ionic samples were collected using $100-\mathrm{ml}$ precleaned PET vials and were transported and kept frozen before 


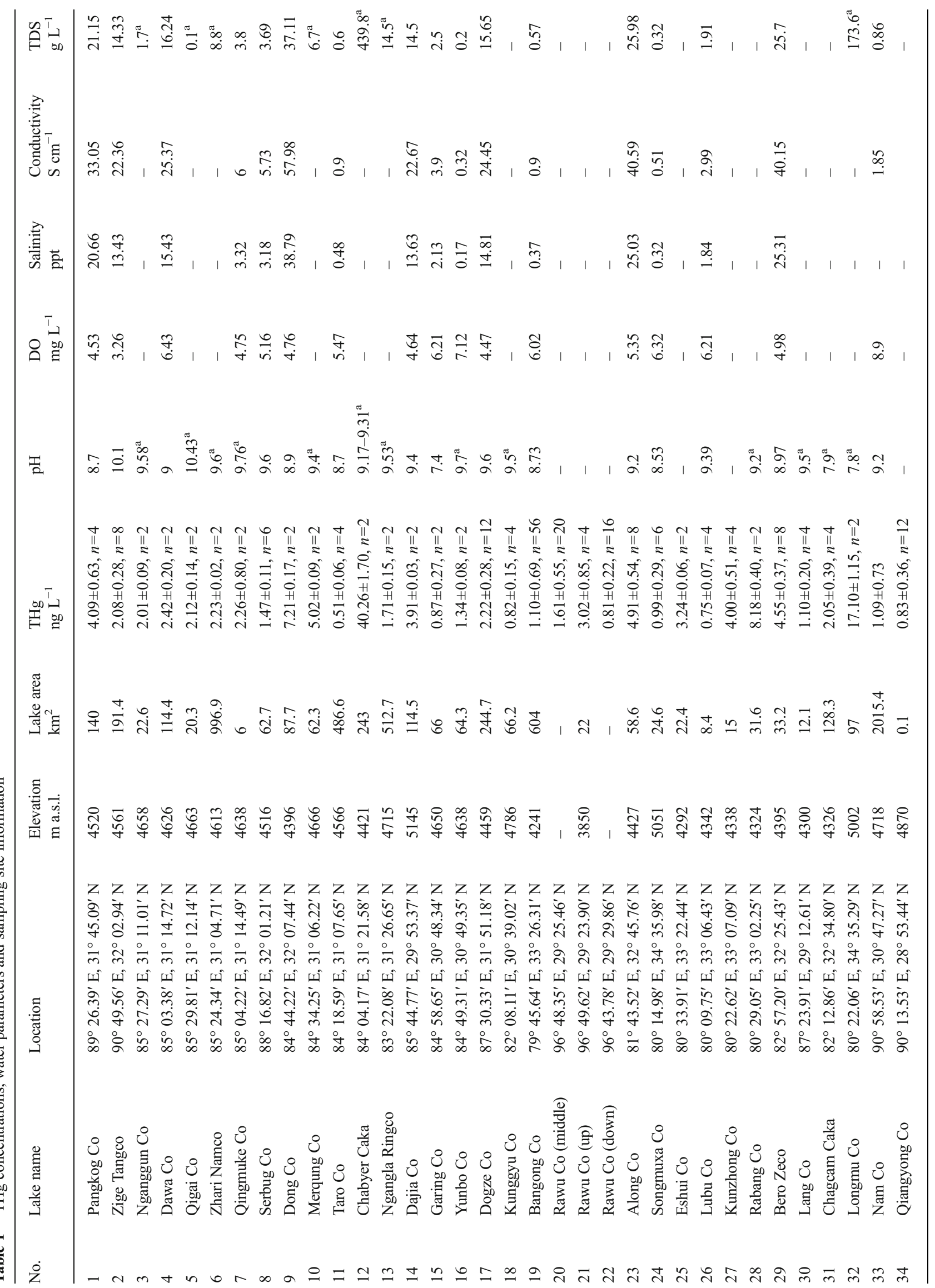




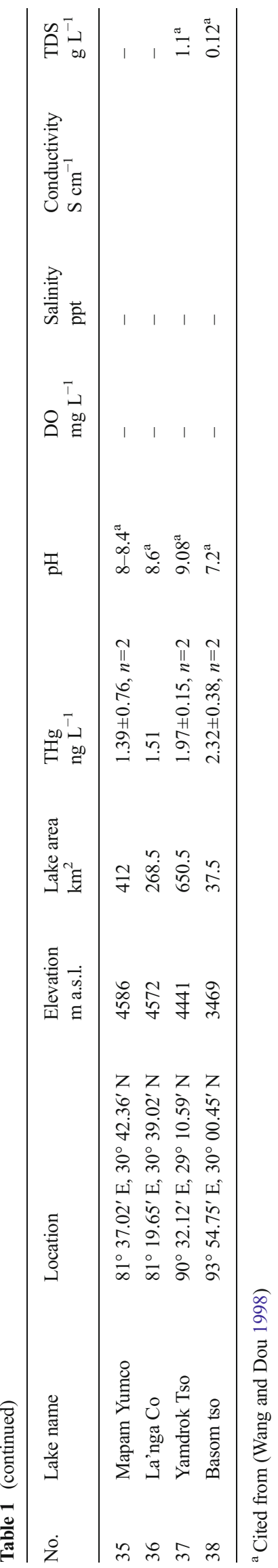

analysis. Water parameters, including $\mathrm{pH}$, temperature, salinity, and salinity-related variables (total dissolved solid (TDS) and electrical conductivity) were measured in situ using a HACH Hydrolab multi-parameter probe.

\section{Analysis of $\mathrm{Hg}$ and major ions}

Hg concentration was quantified by cold vapor atomic fluorescence spectrometry following USEPA Method 1631 (USEPA 2002) using an Analytik-Jena Hg analyzer (Analytik-Jena Corporation Inc., Jena, Germany) in a metalfree Class 100 laminar flow hood placed in a Class 1000 ultraclean laboratory at the Key Laboratory of Tibetan Environment Changes and land surface processes (TEL). Quality assurance and quality control of the analysis were made through an integrated measurement and assessment of replicates, method blanks, field blanks, and ongoing precision and recovery (OPR) standards. In this study, the method detection limit (MDL), defined as three times the standard deviation of ten replicate measurements of a blank solution, was less than $0.2 \mathrm{ng} \mathrm{L}^{-1}$. During $\mathrm{Hg}$ determination, a method blank and an OPR standard of $5 \mathrm{ng} \mathrm{L}^{-1}$ were loaded with a batch of 10-15 samples to check instrument operation. Results showed that method and field blanks were below the MDL with only few of field blank samples lower than $0.3 \mathrm{ng}$ $\mathrm{L}^{-1}$, indicating negligible contamination during sampling, transport, and analysis. The recovery percentage of OPR was $95-105 \%$ of the certified value. The relative standard deviations for all the replicate samples were $<5 \%$. Additionally, sampling and analyzing materials (e.g., Ziploc bags, Falcon tubes, and acid-cleaned glass bottles in Jena MERCUR) were randomly tested for $\mathrm{Hg}$ concentrations, and they were always below the MDL.

Analysis of major ions was also carried out in TEL. Major cations $\left(\mathrm{Ca}^{2+}, \mathrm{Mg}^{2+}, \mathrm{Na}^{+}\right.$, and $\left.\mathrm{K}^{+}\right)$were performed on a Dionex ISC 2000 ion chromatograph equipped with a CSES suppressor using an IonPac CS12A column and $20 \mathrm{mM}$ methanesulfonic acid (MSA) as the eluent. Major anions $\left(\mathrm{Cl}^{-}, \mathrm{NO}_{3}{ }^{-}, \mathrm{HCO}_{3}{ }^{-}\right.$, and $\left.\mathrm{SO}_{4}{ }^{2-}\right)$ were quantified on a Dionex ISC 2500 ion chromatograph equipped with an ASRS suppressor using an IonPac AS11-HC column and $25 \mathrm{mM} \mathrm{KOH}$ as the eluent. The detection limits were $1 \mu \mathrm{g} \mathrm{L}^{-1}$ for all ions, and the analytical precision was within $5 \%$.

\section{Results}

\section{Mercury concentrations in lake waters over the TP}

Average $\mathrm{THg}$ concentrations in surface waters of the sampling lakes varied over a wide range from $<1 \mathrm{ng}$ to $40.3 \mathrm{ng} \mathrm{L}^{-1}$ (Table 1). THg concentrations in most lakes (33 of 38 lakes) 


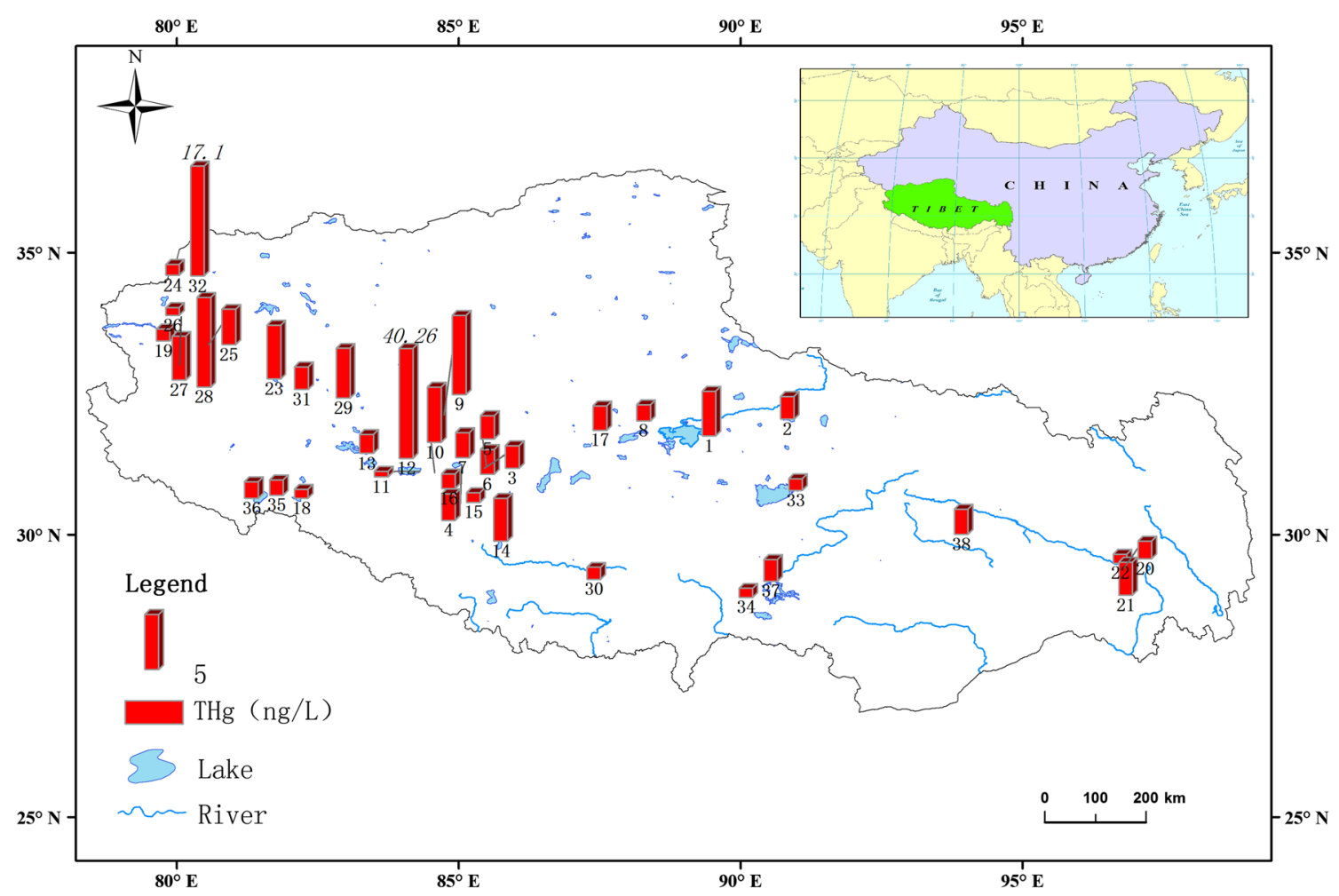

Fig. 1 Map showing the sampling lakes and their averaged THg concentrations in surface waters over the Tibetan Plateau

were lower than $5 \mathrm{ng} \mathrm{L}^{-1}$. Notably, THg concentrations exhibited higher values in Lake Chabyer Caka (no. 12, $40.3 \mathrm{ng}$ $\mathrm{L}^{-1}$ ) and Lake Longmu Co (no. 32, 17.1 $\mathrm{ng} \mathrm{L}^{-1}$ ). Measured water parameters such as salinity, conductivity, TDS, and major ionic concentrations also displayed wide ranges (Table 1). For example, TDS ranged between $<0.1$ and $439.8 \mathrm{~g} \mathrm{~L}^{-1} ; \mathrm{pH}$ values were consistently alkaline and ranged from 7.2 to 10.4 .

\section{Spatial distribution of $\mathrm{Hg}$ in Tibetan lake waters}

As can be seen in Fig. 1, THg concentrations in lake waters showed a general increasing trend along the southeast-northwest transect over the TP. Readers are reminded that relatively less sampling sites are in the southeast TP, and this may reduce the spatial resolution. Nevertheless, it is clear that Hg-enriched lakes concentrated in the northwest region.

\section{Comparison of $\mathrm{Hg}$ concentrations in lake waters over the TP and other areas globally}

Table 2 presented a comparison of THg concentrations in waters from lakes over the TP and other areas globally. Generally, $\mathrm{THg}$ concentrations in Tibetan lake waters $($ mean $=3.82$, median $=2.07)$ are lower than those in lakes influenced by human activity such as Taihu Lake and Dianchi Lake, while they are comparable to those of remote lakes in French Alps and North America and are higher than that of Antarctic lake. Overall, Hg levels in most Tibetan lakes lie within the background $\mathrm{Hg}$ of global natural waters of $<10 \mathrm{ng} \mathrm{L}^{-1}$ (Fitzgerald and Watras 1989), indicating that Tibetan lake waters are minimally influenced by human activity, which is in agreement with previous studies that $\mathrm{Hg}$ levels in various environmental matrix over the TP remain natural background. Nonetheless, Hg concentrations in several lakes are notably high and are comparable to or even exceed those of lakes that suffered from intensive human activities.

\section{Discussion}

\section{Mercury and natural environmental variables}

The distribution of $\mathrm{Hg}$ in aquatic environments is influenced by various chemical and biological parameters in the watershed (Bloom and Effler 1990; Zhang et al. 2009). Principle cluster analysis (PCA) was performed to investigate the interrelations between $\mathrm{Hg}$ concentrations and water physiochemical parameters as well as some other relevant environmental variables of lake watersheds summarized in Electronic supplementary material Table S1. As illustrated in Fig. 2, THg, salinity, and salinity-related water chemical parameters (i.e., 
Table 2 Comparison of $\mathrm{THg}$ concentrations in waters from lakes in the $\mathrm{TP}$ and other areas globally

\begin{tabular}{|c|c|c|c|c|c|c|c|}
\hline \multirow[t]{2}{*}{ Region } & \multirow[t]{2}{*}{ Lakes/location } & \multirow{2}{*}{$\begin{array}{l}\text { Altitude } \\
\text { m a.s.l }\end{array}$} & \multirow[t]{2}{*}{ Period } & \multicolumn{2}{|c|}{$\mathrm{THg}\left(\mathrm{ng} \mathrm{L}^{-1}\right)$} & \multirow[t]{2}{*}{ Remarks } & \multirow[t]{2}{*}{ References } \\
\hline & & & & Mean & Range & & \\
\hline \multirow[t]{4}{*}{ Asia } & 38 lakes, Tibetan Plateau & $3850-5145$ & 2010-2011 & $3.82 \pm 6.75$ & $<1-40.3$ & Remote & This study \\
\hline & Puding Reservoir, China & 1400 & 2006-2007 & $2.74 \pm 2.07$ & $1.0-11.74$ & $\begin{array}{l}\text { Suburban/ } \\
\text { agricultural } \\
\text { activity }\end{array}$ & (Zhang et al. 2009) \\
\hline & Taihu Lake, China & 1887 & 2009 & $28 \pm 18$ & $6.8-83$ & $\begin{array}{l}\text { Urban/intensive } \\
\text { human activity }\end{array}$ & (Wang et al. 2012a) \\
\hline & Dianchi Lake, China & & 2009 & $30 \pm 8.0$ & $18-46$ & $\begin{array}{l}\text { Urban/intensive } \\
\text { human activity }\end{array}$ & (Wang et al. 2012b) \\
\hline \multirow[t]{3}{*}{ Europe } & 4 lakes, French Alps & $1649-2448$ & 2008 & & $0.1-4.34$ & Remote & (Marusczak et al. 2011) \\
\hline & Lake Balaton, Hungary & & $2000-2011$ & & $1.45-6.48$ & Rural & (Nguyen et al. 2005) \\
\hline & Plitvice Lakes, Croatia & $500-650$ & 2005-2007 & 1.22 & $0.73-1.77$ & $\begin{array}{l}\text { Remote/filtered } \\
\text { samples }\end{array}$ & (Vukosav et al. 2014) \\
\hline \multirow[t]{4}{*}{ North America } & Great Lakes & & $2002-2009$ & $1.0 \pm 2.05$ & $0.1-18.2$ & Rural/urban & (Dove et al. 2012) \\
\hline & 60 Lakes, Northern Canada & & 1996 & $3.64 \pm 2.52$ & $0.1-14.7$ & Remote & (Vaidya et al. 2000) \\
\hline & 101 lakes, Western US & $1125-3562$ & 1999 & $1.07 \pm 1.41$ & $0.27-14.09$ & Remote & (Krabbenhoft et al. 2002) \\
\hline & Great Salt Lake, US & 1280 & $2006-2007$ & $3.6 \pm 0.8$ & & Filtered samples & (Peterson and Gustin 2008) \\
\hline Africa & 10 reservoirs, Burkina Faso & & 2009 & 5.3 & $0.4-21.38$ & Mining activity & (Ouedraogo and Amyot 2013) \\
\hline Antarctica & Lake Hoare, Taylor Valley & & 1994 & & $0.66-1.36$ & Remote & (Vandal et al. 1998) \\
\hline
\end{tabular}

conductivity, TDS, and most of ions) converged together and were highly loaded in PC1 (Electronic supplementary material Table S2), indicating close relations between $\mathrm{Hg}$ and these variables. This is further evidenced by the high correlation coefficients among THg and some of the major ions such as $\mathrm{K}^{+}, \mathrm{Na}^{+}$, and $\mathrm{Cl}^{-}$in lake waters (Table 3). Plot of $\mathrm{Hg}$ versus TDS clearly illustrated that $\mathrm{THg}$ covaries with TDS, and such linear relationship is not solely derived from the low $\mathrm{Hg}$ cluster lakes but is also applicable for those high $\mathrm{Hg}$ cluster lakes (Fig. 3).

\section{Distribution and enrichment of mercury in lake waters}

In surface waters, $\mathrm{Hg}$ derives mainly from atmospheric deposition, runoff, and groundwater (Driscoll et al. 2007). Once incorporated into lake water, $\mathrm{Hg}$ exists in elemental,

Table 3 Correlation of $\mathrm{Hg}$ and selected environmental factors in lake waters

\begin{tabular}{|c|c|c|c|c|c|c|c|c|c|c|c|c|c|c|}
\hline & $\mathrm{THg}$ & $\mathrm{pH}$ & Salinity & Conductivity & TDS & DO & $\mathrm{Na}^{+}$ & $\mathrm{NH}_{4}^{+}$ & $\mathrm{K}^{+}$ & $\mathrm{Mg}^{2-}$ & $\mathrm{Ca}^{2-}$ & $\mathrm{Cl}^{-}$ & $\mathrm{HCO}_{3}^{-}$ & $\mathrm{SO}_{4}{ }^{2-}$ \\
\hline $\mathrm{THg}$ & 1.000 & & & & & & & & & & & & & \\
\hline $\mathrm{pH}$ & 0.127 & 1.000 & & & & & & & & & & & & \\
\hline Salinity & $0.972 *$ & 0.221 & 1.000 & & & & & & & & & & & \\
\hline Conductivity & $0.960 *$ & 0.249 & $0.999 *$ & 1.000 & & & & & & & & & & \\
\hline TDS & $0.960 *$ & 0.249 & $0.999 *$ & $1.000 *$ & 1.000 & & & & & & & & & \\
\hline DO & -0.515 & -0.230 & -0.621 & -0.627 & -0.628 & 1.000 & & & & & & & & \\
\hline $\mathrm{Na}^{+}$ & $0.935^{*}$ & 0.450 & $0.918^{*}$ & $0.914 *$ & $0.914^{*}$ & -0.449 & 1.000 & & & & & & & \\
\hline $\mathrm{NH}_{4}^{+}$ & $0.927 *$ & 0.461 & $0.934 *$ & $0.932 *$ & $0.932 *$ & -0.632 & $0.976^{*}$ & 1.000 & & & & & & \\
\hline $\mathrm{K}^{+}$ & $0.990^{*}$ & 0.140 & $0.939 *$ & $0.923 *$ & $0.923 *$ & -0.478 & $0.942 *$ & $0.927^{*}$ & 1.000 & & & & & \\
\hline $\mathrm{Mg}^{2+}$ & $0.930^{*}$ & 0.131 & $0.914 *$ & $0.907^{*}$ & $0.907^{*}$ & -0.281 & $0.887^{*}$ & $0.818^{* *}$ & $0.917 *$ & 1.000 & & & & \\
\hline $\mathrm{Ca}^{2+}$ & 0.546 & -0.387 & 0.581 & 0.579 & 0.579 & -0.085 & 0.336 & 0.272 & 0.488 & $0.716^{* *}$ & 1.000 & & & \\
\hline $\mathrm{Cl}^{-}$ & $0.956^{*}$ & 0.161 & $0.879 *$ & $0.860 *$ & $0.860^{*}$ & -0.330 & $0.940 *$ & $0.891^{*}$ & $0.984 *$ & $0.919^{*}$ & 0.455 & 1.000 & & \\
\hline $\mathrm{HCO}_{3}^{-}$ & -0.014 & $0.786^{* *}$ & 0.100 & 0.129 & 0.129 & -0.493 & 0.209 & 0.327 & -0.041 & -0.197 & -0.602 & -0.102 & 1.000 & \\
\hline $\mathrm{SO}_{4}^{2-}$ & $0.987^{*}$ & 0.168 & $0.964 *$ & $0.954 *$ & $0.954^{*}$ & -0.435 & $0.945^{*}$ & $0.913^{*}$ & $0.982 *$ & $0.973 *$ & 0.599 & $0.966^{*}$ & -0.068 & 1.000 \\
\hline
\end{tabular}

${ }^{*} p \leq 0.01 ;{ }^{*} p \leq 0.05$ 


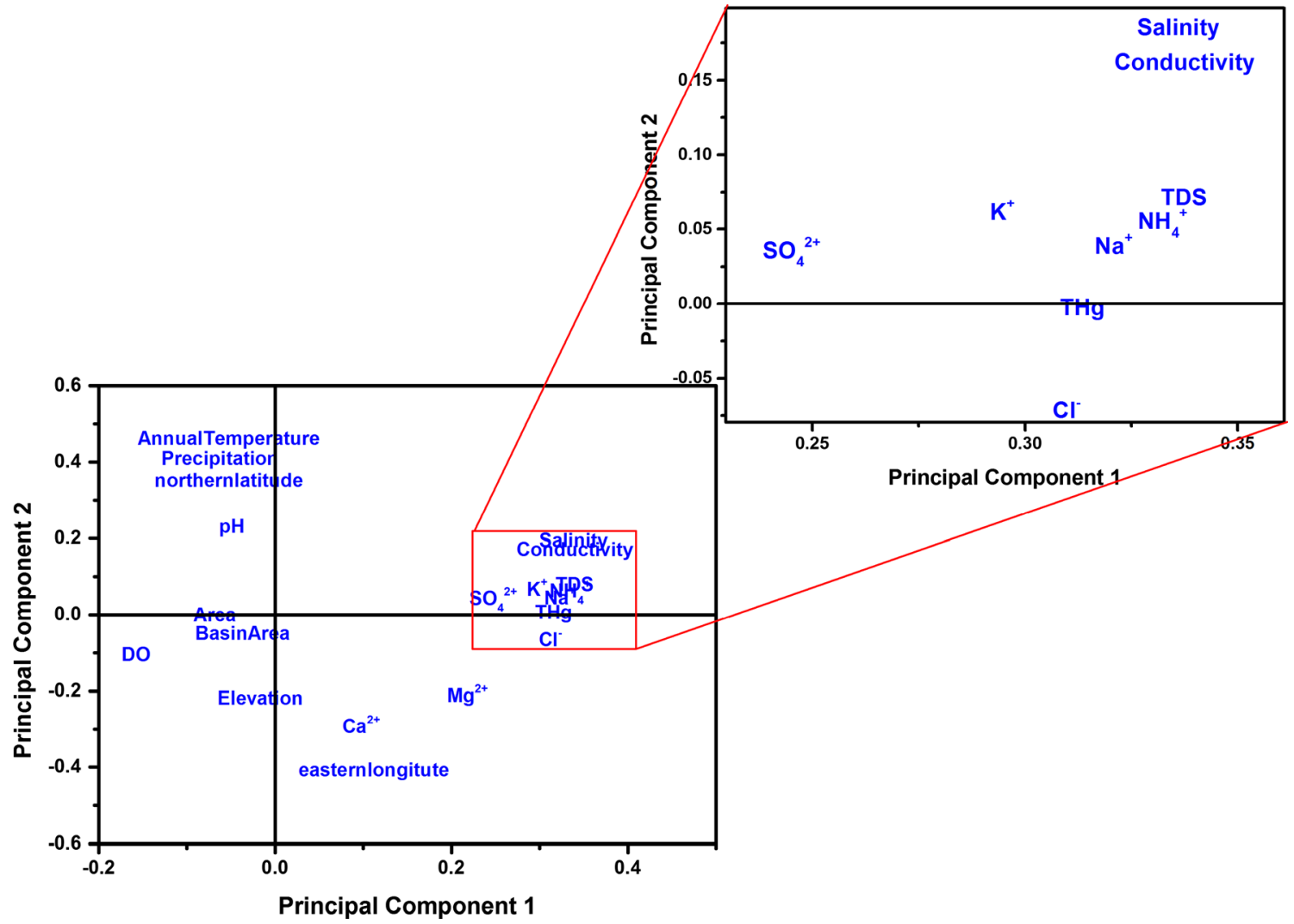

Fig. 2 PCA factors of $\mathrm{Hg}$ and relevant environmental variables

inorganic, and organic forms (Wang et al. 2004), while $\mathrm{Hg}^{2+}$ is recognized as the dominant form (Mousavi et al. 2011). Hg speciation participates in complex environmental and biological processes, and its distribution and fate in lake waters were influenced by multiple factors. Generally, lakes nearby $\mathrm{Hg}$ emission sources, such as industrial and populous areas, are readily receiving more $\mathrm{Hg}$ input and thereby exhibited higher Hg levels. For example, Dove et al. (2012) performed a survey on $\mathrm{Hg}$ distribution in waters from Great Lakes and observed consistently highest $\mathrm{Hg}$ concentrations in the western basin of Lake Erie which is the recipient of intensive urban and industrial inputs. Similarly, Wang et al.
Fig. 3 Correlation between $\mathrm{THg}$ concentration and TDS from the sampling lakes

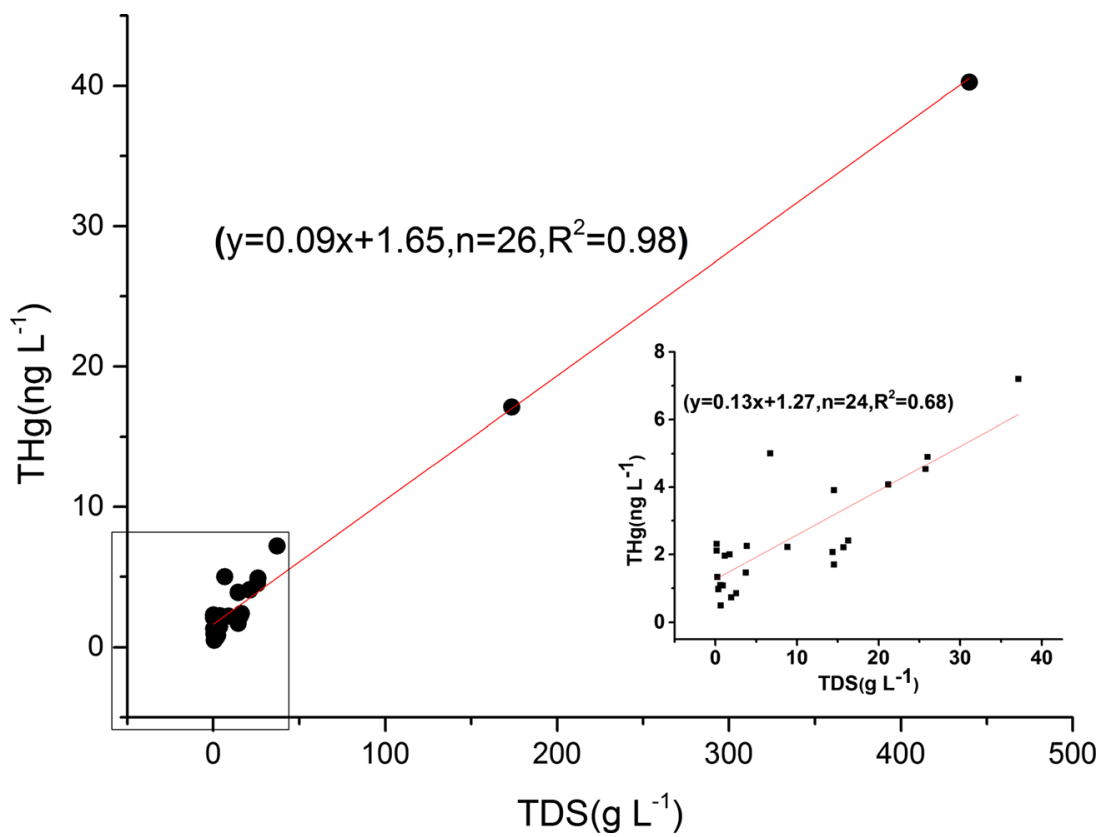


(2012a) reported high $\mathrm{Hg}$ concentrations $\left(6.8-83 \mathrm{ng} \mathrm{L}^{-1}\right)$ in waters from Lake Taihu in Eastern China which suffers $\mathrm{Hg}$ contamination from nearby agricultural and urban inputs. $\mathrm{Hg}$ in waters from the lakes in remote regions generally showed background levels and is from background geologic and/or atmospheric sources. The TP is far from anthropogenic $\mathrm{Hg}$ sources, and the Hg in lakes over the TP is generally attributed to the input of runoff and atmospheric deposition; the latter has been considered the primary $\mathrm{Hg}$ contributor to the remote lakes over the TP (Yang et al. 2010). As shown earlier, Hg concentrations in lakes across the TP exhibited a wide range, with some values exceeding the global background $\mathrm{Hg}$ levels in natural waters. Atmospheric deposition is not likely the major factor resulting in the contrasting $\mathrm{Hg}$ distribution in lake waters; this can be argued by the constant low atmospheric $\mathrm{Hg}$ depositional fluxes over the TP as indicated by glacier snow and lake sediment records, $\mathrm{Hg}$ deposition measurements, and modeling results in the TP (Huang et al. 2012; Wang et al. 2014; Yang et al. 2010; Zhang et al. 2012). Apart from direct atmospheric deposition, $\mathrm{Hg}$ concentrations in lakes are usually dependent on the lithological characteristics of the catchment and/or on weathering and leaching of soils (Yang et al. 2002). It has been reported that some particular aquatic systems received runoff $\mathrm{Hg}$ as the dominant external $\mathrm{Hg}$ input (Gao et al. 2006; Kang et al. 2000). There are insufficient data sets of quantitative runoff $\mathrm{Hg}$ input for the large clusters of lakes over the TP, precluding further linkages with the variability of $\mathrm{Hg}$ in lake waters to the difference in runoff $\mathrm{Hg}$ input on a large scale over the TP. Nevertheless, soil Hg levels exhibited a decreasing trend along the southeast-northwest transect across the TP (Sheng et al. 2012; Zhang et al. 2002), which is exactly the inverse distribution pattern compared with that of $\mathrm{Hg}$ in lake waters, possibly suggesting that catchment lithology and runoff $\mathrm{Hg}$ input are not major factors controlling the distribution of $\mathrm{Hg}$ in lake waters over the TP.

As presented earlier, $\mathrm{Hg}$ concentrations showed a strong correlation with salinity and salinity-related parameters in lake waters (Fig. 3 and Table 3). The salinity of the lakes over the TP is closely related to the natural climatic and environmental conditions and exhibits an increasing trend from south and southeast to north and northwest, co-varying closely with the annual precipitation and aridity (expressed as annual evaporation/annual precipitation) of the TP (Zheng and Liu 2009). Consequently, lakes in the TP exhibit transitions in the order of fresh water lakes, saline lakes, and highly saline lakes along the South/East-North/West gradient (CAS 1984; Zhang et al. 2008). This basic distribution pattern of lakes greatly affects the variation of many lake water parameters such as stable isotopes (e.g., deuterium and dissolved inorganic carbon isotope) (Lei et al. 2012; Yuan et al. 2011), organic compounds (e.g., alkenone) (Liu et al. 2011), diatoms (Yang et al. 2001), and bacteria community (Liu et al. 2013). This is typically explained that lake waters can accumulate or regulate

substances while undergoing evaporation enrichment. $\mathrm{Hg}$ in lake waters is likely regulated by the similar mechanism, as illustrated in Fig. 4. With the decrease of precipitation and increase of evaporation northwards/westwards, lake water evolved to be concentrated with more soluble substances such as salts and dissolved organic matters (DOM) (Hammer 1986); this phenomenon has been observed in many regions as well as the TP itself globally (Anderson and Stedmon 2007; $\mathrm{Xu}$ et al. 2013). $\mathrm{Hg}$ is known to be readily complexed by various natural organic ligands (Guentzel et al. 1996; Han and Gill 2005), which are prone to enrich in high salinity lakes. Therefore, the concurrent high $\mathrm{Hg}$ and salinity in lake waters indicate the effect of the natural environment on the distribution of lake water chemistry over the TP, suggestive of consistent enrichment of $\mathrm{Hg}$ and other soluble substances in lake waters induced by evapoconcentration. Therefore, it is the within-lake process, rather than the direct input of $\mathrm{Hg}$, that induced almost uniformly higher $\mathrm{Hg}$ levels in lakes in the northwest that those in the southeast of the TP.

\section{Perspectives on $\mathrm{Hg}$ biogeochemical study over the TP}

Long-range transport of atmospheric $\mathrm{Hg}$ to remote regions such as the Arctic and Antarctica has been significantly enhanced due to industrialization, and the subsequent fate of $\mathrm{Hg}$ and its potential risk have raised substantial concerns (Bargagli 2008; MacDonald et al. 2000; Poissant et al. 2008). As the low-altitude counterpart of the Polar Regions, the TP and its surrounding mountainous regions as a whole

Northwest

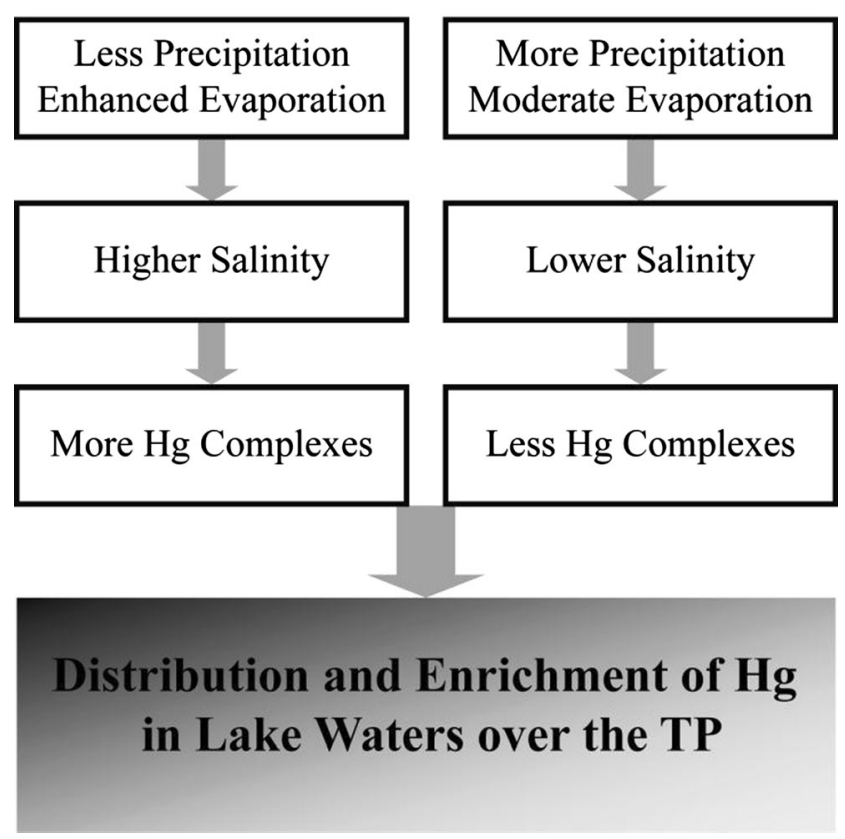

Fig. 4 Illustration of relations between the natural environment and the distribution and enrichment of $\mathrm{Hg}$ in lake waters over the TP 
are known as "The Third Pole" (Qiu 2008; Yao et al. 2012), while Hg's fate and the basic picture of biogeochemical cycling over this unique region have been less known. The TP boasts the most populous high-altitude lakes globally which are of particular importance as potential sinks of $\mathrm{Hg}$ and repositories of historical Hg deposition. Recent studies have revealed altered atmospheric $\mathrm{Hg}$ levels in the last few decades via lake sediments in the TP (Wang et al. 2010; Yang et al. 2010); additionally, the TP has been highlighted as ecologically critical environment with the occurrence of high levels of $\mathrm{Hg}$ in indigenous wild fishes (Yang et al. 2011; Zhang et al. 2014). Our results provided fundamental background of $\mathrm{Hg}$ levels in lake waters for further $\mathrm{Hg}$ investigation over the TP. Besides, the high levels of $\mathrm{Hg}$ in saline lakes induced by evaporation enrichment represent an important natural mechanism of $\mathrm{Hg}$ accumulation within the saline lakes. While much emphasis has been on assessing the impact of direct atmospheric deposition and watershed runoff input of $\mathrm{Hg}$ on remote lake ecosystems, the enhancement of $\mathrm{Hg}$ in waters induced by within-lake processes, as presented in this study, urges for further attention to probe into additional $\mathrm{Hg}$ accumulation mechanisms within the lake itself. Lakes over the TP are generally deep and have long water renewal times (Wang and Dou 1998), allowing long retention and sufficient transformation of $\mathrm{Hg}$ therein. The accumulation and potential methylation of $\mathrm{Hg}$ within lakes are likely further enhanced in the presence of $\mathrm{Cl}^{-}$which is typically one of the dominant ions in Tibetan lakes and can suppress the degradation of methyl-Hg (Sun et al. 2013; Zhang and Hsu-Kim 2010). Although methyl-Hg has not been measured in this study, considering that methyl-Hg generally accounts proportionally to THg in natural waters (Hamasaki et al. 1995), the methyl$\mathrm{Hg}$ concentration and its potential accumulation could be substantially higher in saline lakes over the TP. In the future, studies on $\mathrm{Hg}$ dynamics and bioaccumulation in lakes are needed to depict a full picture of the fate and environmental significance of $\mathrm{Hg}$ in lakes over the TP.

\section{Conclusions}

To sum up, $\mathrm{Hg}$ in Tibetan lake waters exhibited a wide range from $<1$ to $40.3 \mathrm{ng} \mathrm{L}^{-1}$. Hg had a strong correlation with salinity and salinity-related water parameters especially for TDS and some of the major soluble ions such as $\mathrm{K}^{+}, \mathrm{Na}^{+}$, and $\mathrm{Cl}^{-}$. The spatial distribution of $\mathrm{Hg}$ in lake waters showed a general increasing trend along the southeast-northwest transect across the TP, resulting from the increasing evaporation enrichment of lake water chemistry influenced by the natural environment over the TP. The relatively high $\mathrm{Hg}$ levels in saline lakes represent a natural accumulation mechanism of $\mathrm{Hg}$. The Hg dynamics and bioaccumulation in lakes over the TP under the changing climate context warrant further study.
Acknowledgments This work was supported by the National Natural Science Foundation of China (41101064, 41371088, and 41225002) and the "Strategic Priority Research Program (B)" of the Chinese Academy of Sciences (XDB03030504). The authors thank the 2010 and 2011 Expedition Team to Tibetan lakes.

Compliance with Ethical Standards The authors declare no competing financial interest. This article does not contain any studies with human participants or animals performed by any of the authors. Informed consent was obtained from all individual participants included in the study.

\section{References}

Anderson NJ, Stedmon CA (2007) The effect of evapoconcentration on dissolved organic carbon concentration and quality in lakes of SW Greenland. Freshw Biol 52:280-289

Bargagli R (2008) Environmental contamination in Antarctic ecosystems. Sci Total Environ 400:212-226

Bloom NS, Effler SW (1990) Seasonal variability in the mercury speciation of Onondaga Lake (New York). Water Air Soil Pollut 53:251265

CAS (1984) Rivers and lakes of Xizang. Science Press, Beijing

Dove A, Hill B, Klawunn P, Waltho J, Backus S, McCrea RC (2012) Spatial distribution and trends of total mercury in waters of the Great Lakes and connecting channels using an improved sampling technique. Environ Pollut 161:328-334

Driscoll CT, Han YJ, Chen CY, Evers DC, Lambert KF, Holsen TM, Kamman NC, Munson RK (2007) Mercury contamination in forest and freshwater ecosystems in the Northeastern United States. Bioscience 57:17-28

Fitzgerald WF (1999) Clean hands, dirty hands: Clair Patterson and the aquatic biogeochemistry of mercury. Clean Hands: Clair Patterson's crusade against environmental lead contamination. Nova Science, Commack, pp 119-137

Fitzgerald WF, Watras CJ (1989) Mercury in surficial waters of rural Wisconsin lakes. Sci Total Environ 87-8:223-232

Fitzgerald WF, Engstrom DR, Mason RP, Nater EA (1998) The case for atmospheric mercury contamination in remote areas. Environ Sci Technol 32:1-7

Fliedner A, Ruedel H, Knopf B, Weinfurtner K, Paulus M, Ricking M, Koschorreck J (2014) Spatial and temporal trends of metals and arsenic in German freshwater compartments. Environ Sci Pollut Res 21:5521-5536

Fu XW, Feng X, Liang P, Deliger ZH, Ji J, Liu P (2012) Temporal trend and sources of speciated atmospheric mercury at Waliguan GAW station, Northwestern China. Atmos Chem Phys 12:1951-1964

Gao N, Armatas NG, Shanley JB, Kamman NC, Miller EK, Keeler GJ, Scherbatskoy T, Holsen TM, Young T, Mcllroy L, Drake S, Olsen B, Cady C (2006) Mass balance assessment for mercury in Lake Champlain. Environ Sci Technol 40:82-89

Guentzel JL, Powell RT, Landing WM, Mason RP (1996) Mercury associated with colloidal material in an estuarine and an open-ocean environment. Mar Chem 55:177-188

Hamasaki T, Nagase H, Yoshioka Y, Sato T (1995) Formation, distribution, and ecotoxicity of methylmetals of tin, mercury, and arsenic in the environment. Crit Rev Environ Sci Technol 25:45-91

Hammer UT (1986) Saline lake ecosystems of the world, 59. Springer, Netherland

Han SH, Gill GA (2005) Determination of mercury complexation in coastal and estuarine waters using competitive ligand exchange method. Environ Sci Technol 39:6607-6615 
Harris RC et al (2007) Whole-ecosystem study shows rapid fish-mercury response to changes in mercury deposition. Proc Natl Acad Sci U S A 104:16586-16591

Huang J, Kang SC, Zhang QG, Yan HY, Guo JM, Jenkins MG, Zhang GS, Wang K (2012) Wet deposition of mercury at a remote site in the Tibetan Plateau: concentrations, speciation, and fluxes. Atmos Environ 62:540-550

Kang WJ, Trefry JH, Nelsen TA, Wanless HR (2000) Direct atmospheric inputs versus runoff fluxes of mercury to the lower Everglades and Florida Bay. Environ Sci Technol 34:4058-4063

Krabbenhoft DP, Olson ML, Dewild JF, Clow DW, Striegl RG, Dornblaser MM, VanMetre P (2002) Mercury loading and methylmercury production and cycling in high-altitude lakes from the western United States. Water Air Soil Pollut Focus 2:233-249

Lei YB, Yao TD, Sheng YW, Zhang EL, Wang WC, Li JL (2012) Characteristics of delta C-13(DIC) in lakes on the Tibetan Plateau and its implications for the carbon cycle. Hydrol Process 26:535543

Liu XD, Chen BD (2000) Climatic warming in the Tibetan Plateau during recent decades. Int J Climatol 20:1729-1742

Liu WG, Liu ZH, Wang HY, He YX, Wang Z, Xu LM (2011) Salinity control on long-chain alkenone distributions in lake surface waters and sediments of the northern Qinghai-Tibetan Plateau, China. Geochim Cosmochim Acta 75:1693-1703

Liu Y, Yao T, Jiao N, Zhu L, Hu A, Liu X, Gao J, Chen Z-Q (2013) Salinity impact on bacterial community composition in five highaltitude lakes from the Tibetan Plateau, Western China. Geomicrobiol J 30:462-469

Ma R, Yang G, Duan H, Jiang J, Wang S, Feng X, Li A, Kong F, Xue B, Wu J, Li S (2011) China's lakes at present: number, area and spatial distribution. Sci China Earth Sci 54:283-289

MacDonald RW et al (2000) Contaminants in the Canadian Arctic: 5 years of progress in understanding sources, occurrence and pathways. Sci Total Environ 254:93-234

Marusczak N, Larose C, Dommergue A, Paquet S, Beaulne J-S, MauryBrachet R, Lucotte M, Nedjai R, Ferrari CP (2011) Mercury and methylmercury concentrations in high altitude lakes and fish (Arctic charr) from the French Alps related to watershed characteristics. Sci Total Environ 409:1909-1915

Mason RP, Fitzgerald WF, Morel FMM (1994) The biogeochemical cycling of elemental mercury: anthropogenic influences. Geochim Cosmochim Acta 58:3191-3198

Mergler D, Anderson HA, Chan LHM, Mahaffey KR, Murray M, Sakamoto M, Stern AH (2007) Methylmercury exposure and health effects in humans: a worldwide concern. Ambio 36:3-11

Mousavi A, Chavez RD, Ali AMS, Cabaniss SE (2011) Mercury in natural waters: a mini-review. Environ Forensic 12:14-18

Nguyen HL, Leermakers M, Kurunczi S, Bozo L, Baeyens W (2005) Mercury distribution and speciation in Lake Balaton, Hungary. Sci Total Environ 340:231-246

Nimick DA, Caldwell RR, Skaar DR, Selch TM (2013) Fate of geothermal mercury from Yellowstone National Park in the Madison and Missouri Rivers, USA. Sci Total Environ 443:40-54

Ouedraogo O, Amyot M (2013) Mercury, arsenic and selenium concentrations in water and fish from sub-Saharan semi-arid freshwater reservoirs (Burkina Faso). Sci Total Environ 444:243-254

Peterson C, Gustin M (2008) Mercury in the air, water and biota at the Great Salt Lake (Utah, USA). Sci Total Environ 405:255-268

Phillips VJA, St Louis VL, Cooke CA, Vinebrooke RD, Hobbs WO (2011) Increased mercury loadings to Western Canadian Alpine Lakes over the past 150 years. Environ Sci Technol 45:2042-2047

Poissant L, Zhang HH, Canario J, Constant P (2008) Critical review of mercury fates and contamination in the arctic tundra ecosystem. Sci Total Environ 400:173-211

Qiu J (2008) The third pole. Nature 454:393-396
Schindler DW (2009) Lakes as sentinels and integrators for the effects of climate change on watersheds, airsheds, and landscapes. Limnol Oceanogr 54:2349-2358

Sheng JJ, Wang XP, Gong P, Tian LD, Yao TD (2012) Heavy metals of the Tibetan top soils Level, source, spatial distribution, temporal variation and risk assessment. Environ Sci Pollut Res 19:3362-3370

Sun H, Liao K, Pan Y, Wang J (1990) Atlas of the Qinghai-Tibet Plateau (in Chinese). Science Press, Beijing

Sun R, Wang D, Zhang Y, Mao W, Zhang T, Ma M, Zhang C (2013) Photo-degradation of monomethylmercury in the presence of chloride ion. Chemosphere 91:1471-1476

Swain EB, Engstrom DR, Brigham ME, Henning TA, Brezonik PL (1992) Increasing rates of atmospheric mercury deposition in Midcontinental North America. Science 257:784-787

USEPA (2002) Method 1631, revision E: mercury in water by oxidation, purge and trap, and cold vapor atomic fluorescence spectrometry. US Environmental Protection Agency Washington, DC, Washington

Vaidya OC, Howell GD, Leger DA (2000) Evaluation of the distribution of mercury in lakes in Nova Scotia and Newfoundland (Canada). Water Air Soil Pollut 117:353-369

Vandal GM, Mason RP, McKnight D, Fitzgerald W (1998) Mercury speciation and distribution in a polar desert lake (Lake Hoare, Antarctica) and two glacial meltwater streams. Sci Total Environ 213:229-237

Vukosav P, Mlakar M, Cukrov N, Kwokal Z, Pizeta I, Pavlus N, Spoljaric I, Vurnek M, Brozincevic A, Omanovic D (2014) Heavy metal contents in water, sediment and fish in a karst aquatic ecosystem of the Plitvice Lakes National Park (Croatia). Environ Sci Pollut Res 21:3826-3839

Wang S, Dou H (1998) China lake records. Science Press, Beijing

Wang QR, Kim D, Dionysiou DD, Sorial GA, Timberlake D (2004) Sources and remediation for mercury contamination in aquatic systems - a literature review. Environ Pollut 131:323-336

Wang X, Yang H, Gong P, Zhao X, Wu G, Turner S, Yao T (2010) One century sedimentary records of polycyclic aromatic hydrocarbons, mercury and trace elements in the Qinghai Lake, Tibetan Plateau. Environ Pollut 158:3065-3070

Wang SF, Xing DH, Jia YF, Li BA, Wang KL (2012a) The distribution of total mercury and methyl mercury in a shallow hypereutrophic lake (Lake Taihu) in two seasons. Appl Geochem 27:343-351

Wang S, Zhang M, Li B, Xing D, Wang X, Wei C, Jia Y (2012b) Comparison of mercury speciation and distribution in the water column and sediments between the algal type zone and the macrophytic type zone in a hypereutrophic lake (Dianchi Lake) in Southwestern China. Sci Total Environ 417:204-213

Wang L, Wang S, Zhang L, Wang Y, Zhang Y, Nielsen C, McElroy MB, Hao J (2014) Source apportionment of atmospheric mercury pollution in China using the GEOS-Chem model. Environ Pollut 190: $166-175$

Xu H, Lan J, Liu B, Sheng E, Yeager KM (2013) Modern carbon burial in Lake Qinghai, China. Appl Geochem 39:150-155

Yang XD, Wang SM, Xia WL, Li WC (2001) Application of CCA for study on modern lake diatoms and environment in the Tibetan Plateau. Sci China Ser D Earth Sci 44:343-350

Yang HD, Rose NL, Battarbee RW (2002) Distribution of some trace metals in Lochnagar, a Scottish mountain lake ecosystem and its catchment. Sci Total Environ 285:197-208

Yang HD, Battarbee RW, Turner SD, Rose NL, Derwent RG, Wu GJ, Yang RQ (2010) Historical reconstruction of mercury pollution across the Tibetan Plateau using lake sediments. Environ Sci Technol 44:2918-2924

Yang RQ, Jing CY, Zhang QH, Wang ZH, Wang YW, Li YM, Jiang GB (2011) Polybrominated diphenyl ethers (PBDEs) and mercury in fish from lakes of the Tibetan Plateau. Chemosphere 83:862-867 
Yao T, Thompson LG, Mosbrugger V, Zhang F, Ma Y, Luo T, Xu B, Yang X, Joswiak DR, Wang W (2012) Third pole environment (TPE). Environ Dev 3:52-64

Yuan FS, Sheng YW, Yao TD, Fan CJ, Li JL, Zhao H, Lei YB (2011) Evaporative enrichment of oxygen-18 and deuterium in lake waters on the Tibetan Plateau. J Paleolimnol 46:291-307

Zhang T, Hsu-Kim H (2010) Photolytic degradation of methylmercury enhanced by binding to natural organic ligands. Nat Geosci 3:473476

Zhang XPP, Deng W, Yang XMM (2002) The background concentrations of 13 soil trace elements and their relationships to parent materials and vegetation in Xizang (Tibet), China. J Asian Earth Sci 21:167174

Zhang QG, Kang SC, Wang FY, Li CL, Xu YW (2008) Major ion geochemistry of Nam Co Lake and its sources, Tibetan Plateau. Aquat Geochem 14:321-336
Zhang J, Feng X, Yan H, Guo Y, Yao H, Meng B, Liu K (2009) Seasonal distributions of mercury species and their relationship to some physicochemical factors in Puding Reservoir, Guizhou, China. Sci Total Environ 408:122-129

Zhang QG, Huang J, Wang FY, Mark LW, Xu JZ, Armstrong D, Li CL, Zhang YL, Kang SC (2012) Mercury distribution and deposition in glacier snow over Western China. Environ Sci Technol 46:54045413

Zhang Q, Pan K, Kang S, Zhu A, Wang W-X (2014) Mercury in wild fish from high-altitude aquatic ecosystems in the Tibetan Plateau. Environ Sci Technol 48:5220-5228

Zheng MP, Liu XF (2009) Hydrochemistry of salt lakes of the QinghaiTibet Plateau, China. Aquat Geochem 15:293-320 